\title{
Rorövovarorsospoproråkoketot: Language Games and Swedish Phonology
}

\author{
Samuel Andersson \\ Yale University
}

\section{Introduction}

This paper examines the phonology of language games (see Bagemihl 1988, 1995, Davis 1993, and Vaux 2011, among others), using two case studies from the Swedish language game Rövarspråket. The framework adopted here is a rule-based implementation of Substance-Free Phonology (see Bale and Reiss forthcoming, Hale and Reiss 2008, Reiss 2018, Samuels 2009, 2011, among others). I focus specifically on Standard Central Swedish (SCSw.), spoken in Stockholm and surrounding areas. It is shown that Rövarspråket can shed light on problems in Swedish phonology, as well as on issues of general theoretical relevance. Using Rövarspråket data, I argue that the newly-discovered process of pre-palatal raising (Andersson 2017a) has been phonologized. This has implications for nasal assimilation, which, because of its interaction with pre-palatal raising, must also have also been phonologized. The argument illustrates the possibility of using language games to investigate whether a process is phonetic or phonological. A formalization of nasal assimilation in terms of phonetic underspecification is proposed, following work on Japanese by Kuroda (1965) and Kochetov (2014). I also discuss the question of productive phonological opacity, hypothesized not to exist in much recent work (Green 2004, 2007, Sanders 2003, among others). Rövarspråket can shed light on this debate, as it productively extends patterns found in the regular phonology of Swedish. I show that a counterfeeding interaction in Swedish is fully productive, suggesting that opacity must be accounted for by our theories of phonology. This is in line with earlier work on language games and opacity (Al-Mozainy 1981, Sherzer 1970) and with other work in phonological theory (Ito and Mester 2003, McCarthy 1999 et seq., Vaux 2008 and others).

The remainder of this paper is structured as follows. In section 2 I present Rövarspråket, outlining how Swedish words are transformed into their language game equivalents. This involves processes of consonant reduplication as well as / $/$ / epenthesis. In sections 3 and 4 , I introduce and analyze data on four phonological processes in SCSw. 3.1 covers the apparent counterfeeding interaction between unstressed vowel shortening and vowel centralization before /r/. In 3.2 I use Rövarspråket to argue that this represents a case of productive phonological opacity. 4.1 introduces data on a transparent, feeding interaction between nasal assimilation and pre-palatal raising, while 4.2 gives a phonological analysis, motivated in part by data from Rövarspråket. Section 5 concludes the paper.

\section{Rövarspråket}

This section covers the language game Rövarspråket, popularized by Astrid Lindgren's books about Kalle Blomkvist, and learned by many Swedish-speaking children. In the game, every consonant $/ \mathrm{C}_{\mathrm{i}} /$ is replaced by the sequence $/ \mathrm{C}_{\mathrm{i}} \mathrm{2} \mathrm{C}_{\mathrm{i}} /$. In other words, every consonant in the SCSw. UR is copied, and the vowel $/ \mathrm{s} /$, written $\langle\mathrm{o}\rangle$, is inserted between copies. As indicated by the title of the paper, the word Rövarspråket comes out as Rorövovarorsospoproråkoketot, with inserted segments underlined. To the output of this algorithm are applied the regular phonological rules of SCSw. This makes Rövarspråket ideal for studies of phonological productivity, something I took advantage of when investigating SCSw. quantity

* I'd like to thank audiences at ULAB2017, audiences at AMP 2017, members of the Yale Phonology Reading Group, four anonymous reviewers, Bert Vaux, and Ollie Sayeed for their feedback on versions of this work. I am also grateful to participants of my survey on Rövarspråket, and to friends at the University of Cambridge, who first made me aware of the palatalization of Swedish velar stops. Without this observation, I would likely never have started this project. All remaining errors are mine.

(C) 2018 Samuel Andersson Proceedings of AMP 2017 


$\begin{array}{lll}\text { UR } & \text { SR } & \text { Translation } \\ / \text { 'mø:bel/2 } & {[\text { 'mø:bel] }} & \text { furniture } \\ \text { /mø:'ble:ra/ } & \text { [mø'ble:ra] } & \text { furnish }\end{array}$

Unstressed /ø:r/ could now go one of two ways. One option is a feeding relationship between vowel shortening and centralization: /ø:r/ $\rightarrow$ œr (shortening) $\rightarrow$ [er] (centralization). Another option is counterfeeding, where /ø:r/ surfaces as [œr], and never as *[er]. Counterfeeding is what we actually find. In (4) the underlying long /ø:/ is part of the verbal prefix /fø:r/, whose long vowel surfaces unchanged under stress (Elert 1981: 83, Riad 2014: 204).

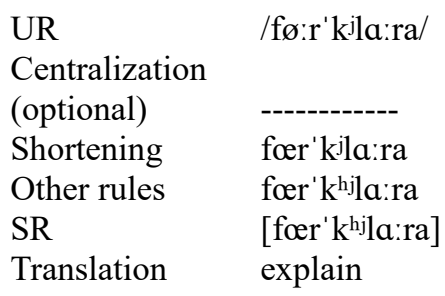

However, more data is needed before we accept that this really is counterfeeding. The examples of centralization in (2) involve stressed syllables, while in (4), the syllable containing [œr] is unstressed. So perhaps centralization applies only to stressed œ, explaining the non-application in (4). A direct test of this hypothesis would be to find forms with unstressed /œ/ before /r/, where the /œ/ cannot be analyzed as /ø:/. If centralization can apply in such forms, it must be productive in unstressed syllables. I have not found any forms relevant for testing this hypothesis. However, an indirect test can be found. Suppose that centralization applies regardless of stress. Unstressed [өr] would then be ambiguous between /er/ and /œr/. This in turn has an impact on the expected spelling: /er/ is written $\langle\operatorname{ur}(\mathrm{r})\rangle$ while /œr/ is written $\langle\ddot{\mathrm{or}}(\mathrm{r})\rangle$. If speakers allow unstressed [өr] to be derived from /œr/, we would expect the possibility of non-standard spellings where this phonetic sequence is rendered as $\langle\ddot{\partial} r(r)\rangle$, despite a standard spelling with $\langle\operatorname{ur}(r)\rangle$. Such spellings are attested: for [ $\mathrm{k}^{\mathrm{h}} \boldsymbol{\theta r a}^{2}$ 'jœm:a] 'hide-and-seek', one finds non-standard $<$ körragömma $>$ (standard < kurragömma $>$ ), and for [ $\mathrm{p}^{\mathrm{h}} \mathrm{t}^{\mathrm{h}} \mathrm{p}^{\mathrm{h}} \boldsymbol{\mathrm { o }}$ 'ri:] 'medley' there is non-standard < pottpörri $>$ (standard $<$ potpurri $>$ ). ${ }^{3}$ These spellings only make sense if people treat unstressed [er] as underlying /œr/, and so we cannot argue that the absence of centralization in (4) is due to the stress pattern. An alternative explanation for the data is required, and in 3.2 below, I will argue for an explanation in terms of productive phonological opacity.

3.2 Analysis In recent years, many linguists have attempted to account for apparently opaque interactions like the one in (4) without relying on the phonology. Examples include Anttila, Fong, Beňuš, and Nycz (2008), Green (2004, 2007), Sanders (2003), Sumner (2003), and Zhang, Lai, and Turnbull-Sailor (2006). All of these works express skepticism about the need for true phonological opacity:

[T] he Singapore English evidence supports the hypothesis that phonological opacity has only one source: the interleaving of phonology and morphology (Anttila et al. 2008: 212)

2 The $[\varepsilon]$ in the surface form may be epenthetic, giving underlying /'mø:bl/ (Morén-Duolljá 2013, Riad 2014 and references therein).

3 The alternative spelling can be found in Swedish blog posts as exemplified by the following for 'hide-and-seek': $<$ blog.liu.se/jonnaelofssonbjesse/2016/09/28/nar-verkligheten-bankar-pa-dorren/>, and for 'medley', an example of the non-standard spelling can be found at $<$ http://daysofsandy.blogg.se/2007/june/pottporri.html $>$. 
The results suggest the possibility that all crosslinguistic instances of apparent opacity can be explained in terms of the phonologymorphology interface and that purely phonological opacity does not exist (Green 2004: 37, emphasis in original)

My analysis supports the hypothesis of Sanders (2003) that there is no instance of opacity in a purely phonological relationship (Green 2007: 52)

[I]f a framework even allows synchronically productive opacity, it is likely too powerful and should be restricted (Sanders 2003: 229)

This research also has implications for opacity in general, casting doubt on the assumption that speakers really do acquire opaque generalizations (Sumner 2003: iv)

This [the authors' results - SA] casts further doubt on the productivity of opaque phonological patterns (Zhang et al. 2006: 460)

As these quotes reveal, alternative explanations for apparent opacity often involve morphology and morphophonology (though see Hale and Reiss 2008: 64-65 for a phonetic explanation of an apparent chain shift in child English). The SCSw. data in (4) are also susceptible to a morphological explanation. The opacity is only observed when the sequence /ø:r/ is unstressed, a situation which is essentially limited to the single verbal prefix /fø:r/. Perhaps, then, the counterfeeding is a fact about this prefix, and not a fact about SCSw. phonology. We can investigate this hypothesis using language games, which allow us to easily test if a generalization productively applies to new words outside of their normal morphological environments.

There is a long history of providing evidence for opacity from language games. The earliest such source I am aware of is Sherzer (1970), on the opaque interaction between stress assignment and /i/ epenthesis in Guna. Al-Mozainy (1981), working on Bedouin Hijazi Arabic, is another early reference. Here I extend this methodology to SCSw. As we saw in section 2, Rövarspråket almost always shifts stress to one of the inserted / $/$ vowels. This makes the stressed syllable in the SCSw. word unstressed, which triggers unstressed vowel shortening (see 'save (verb)' in (1) above). If the opaque interaction with centralization is productive, new short vowels created in this way should never undergo centralization. But if the opacity-skeptic conclusions cited above are correct, we should find that shortening feeds centralization, allowing newly-created unstressed vowels to centralize. In (5) I show that the former view is correct: the opaque, counterfeeding interaction between shortening and centralization is productive in Rövarspråket.

$\begin{array}{ll}\text { SCSw. UR } & \text { /'bø:r/ } \\ \text { Rövarspråket UR /bobø: 'ror/ } \\ \begin{array}{ll}\text { Centralization } \\ \text { (optional) }\end{array} \\ \begin{array}{ll}\text { Shortening } & \text {---------- } \\ \text { Other rules } & \text { bobø' ror } \\ \text { SR } & \text { [bobø' } \\ \text { Translation } & \text { ought to, should }\end{array}\end{array}$

The order of the rules in (5) is exactly the same as that presented in (4), and this ordering correctly predicts the ungrammaticality of $*$ [bobe'ror:], where shortening and centralization are in a transparent, feeding relationship. My position on opacity, then, is that although individual cases may be reanalyzed as nonphonological, such a reanalysis is not always possible. This echoes work such as McCarthy (1999), 
providing a list of various types of external evidence that opacity is psychologically real. He concludes that "the move of simply discarding all opaque generalisations is not very promising" (McCarthy 1999: 383). See also Ito and Mester (2003), who say that their research "underscores /.../ the general finding that opacity is a solid fact of phonological life" (Ito and Mester 2003: 297). Proponents of various forms of rule-based phonology are also adherents of this view (Andersson 2017b, Hale and Reiss 2008, Samuels 2009, Vaux 2008 among others), as opacity is predicted to exist by the basic mechanism of rule ordering (Hale and Reiss 2008: 67, footnote 8).

In conclusion, it is beyond reasonable doubt that phonological opacity exists, and any adequate theory of phonology must be able to capture opaque patterns. Although some have questioned this conclusion, external evidence for opacity has a long history in the linguistics literature, not always adequately addressed by skeptics. Rövarspråket adds to this body of evidence, by showing that speakers treat a case of SCSw. counterfeeding as purely phonological, even though the internal evidence from SCSw. is equally consistent with a morphological analysis. The data can be successfully analyzed in rule-based phonology.

\section{Feeding}

In this section we are concerned with two more processes in SCSw., where it is not immediately clear that either should receive a phonological explanation. I outline the data in 4.1, and argue for a phonological analysis of both processes in 4.2 .

4.1 Data Andersson (2017a) discusses a process of pre-palatal raising, described as an innovative feature in young middle- and upper-class speakers of SCSw. However, I have since heard a similar pattern of allophony in Värmland Swedish, and it is not clear whether the SCSw. pattern really represents an innovation. Andersson (2017a) writes the process as in (6):

$$
\varepsilon, \propto \rightarrow \mathrm{e}, \varnothing / \_\{k, g, \mathrm{y}, \mathrm{j}, \mathrm{i}:, \mathrm{I}, \mathrm{y}:, \mathrm{y}, \mathrm{e}: /\}
$$

That is, the short mid front vowels become tense before any of the phonemes in curly brackets \{\} . I would like to revise this description so as to exclude vowels from the triggering context for the rule, a choice explained below (7). It is also important to note that the velar stops in SCSw. are almost always palatalized (see section 4.2 for more discussion). The revised rule is then as in (7):

$$
\varepsilon, \propto \rightarrow \mathrm{e}, \varnothing / \_\left\{\mathrm{k}^{\mathrm{j}}, \mathrm{g}^{\mathrm{j}}, \mathrm{y}^{\mathrm{j}}, \mathrm{j}\right\}
$$

Vowels are excluded from the set of triggers as all SCSw. speakers, even those without the rule in (7), realize $/ \varepsilon /$ as [e] before another vowel, as exemplified in (8). It is likely that this is part of a larger process affecting vowels other than $/ \varepsilon /$, a question that will not be explored further here.

$$
\begin{aligned}
& \text { UR } \quad \text { SR } \quad \text { Translation } \\
& { }^{2}{ }^{\prime} \text { nitşe }\left.\right|^{4} \quad \text { [ }{ }^{2} \text { nIt:se] Nietzsche }
\end{aligned}
$$

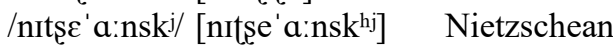

The pre-palatal raising rule in (7) interacts with a process of nasal assimilation which affects preconsonantal $/ \mathrm{n} /$. Some examples of nasal assimilation are given in (9). A full formalization of assimilation is not needed to study the interaction with raising, and the details are left for section 4.2.

4 An alternative UR would be ${ }^{2}$ 'nIrts $/$, producing the same SR by retroflexion (see section 3.1). I am not aware of any arguments favoring one UR over the other, and (3) simply uses the one suggested by the orthography. 


\begin{tabular}{|c|c|c|}
\hline $\begin{array}{l}\text { UR } \\
\text { /hon }{ }^{2} \text { bu:rde/ } \\
\text { /hon 'ta:r/ } \\
\text { /hon 'kjan/ }\end{array}$ & 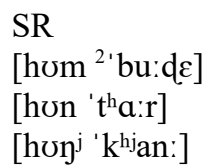 & $\begin{array}{l}\text { Translation } \\
\text { she should ... } \\
\text { she takes ... } \\
\text { she can ... }\end{array}$ \\
\hline
\end{tabular}

Notice that pre-palatal raising in (7) is triggered by a following $\mathrm{y}^{\mathrm{j}}$ but not by a following $\mathrm{n}$. Notice also that nasal assimilation creates new examples of $\mathrm{y}^{\mathrm{j}}$ from underlying $/ \mathrm{n} /$. A question immediately arises: what

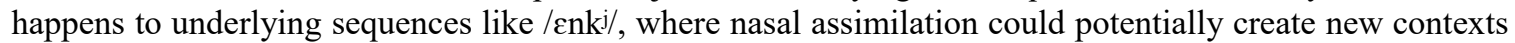
for raising? Do such sequences involve feeding or counterfeeding? (10) illustrates that in forms like these, the processes are in a feeding relationship:

\begin{tabular}{|c|c|}
\hline UR & /عn 'kjat/ \\
\hline Assimilation & $\varepsilon \eta^{\mathrm{j}}$ 'kjat \\
\hline Raising & enj 'kjat \\
\hline $\begin{array}{l}\text { Other rules } \\
\text { SR }\end{array}$ & $\begin{array}{l}\text { en j ' } k^{\mathrm{hj}} \mathrm{at}^{\mathrm{h}} \text { : } \\
{\left[\mathrm{Cn}^{\mathrm{j}} \mathrm{k}^{\mathrm{hj}} \mathrm{th}^{\mathrm{h}}\right.}\end{array}$ \\
\hline $\begin{array}{l}\text { SR } \\
\text { Translation }\end{array}$ & $\begin{array}{l}{[e]^{j} k^{1}} \\
\text { a cat }\end{array}$ \\
\hline
\end{tabular}

The discussion so far has assumed that both raising and assimilation are phonological processes, part of ordered derivations like the one above. However, it is also possible that they represent simple phonetic coarticulatory effects, which have not yet been phonologized. This choice between phonetic and phonological analyses is the subject of the next section.

4.2 Analysis Here I will attempt to defend various plausible phonetic explanations for pre-palatal raising, before coming to the conclusion that a phonological analysis is preferable. Nasal assimilation is treated later in the section, as I believe that the solution to the problem of raising should inform our analysis of assimilation.

Notice that raising of $[\varepsilon, \propto]$ to $[e, \varnothing]$ involves raising the tongue towards the palate. The process applies before segments involving a constriction in the palatal region. A phonetic explanation is possible here: when the body aims for $[\varepsilon, œ]$, the tongue is pulled up towards the palate by segments which themselves require a palatal articulation. However, this explanation is insufficient. The palatalized velars $/ \mathrm{k}^{\mathrm{j}}, \mathrm{g}, \mathrm{j}^{\mathrm{j} /}$ can trigger raising even when they surface as plain velar $[\mathrm{k}, \mathrm{g}, \mathrm{\eta}]$. These unpalatalized realizations are often found before back vowels, so that $/ \mathrm{k}^{\mathrm{j}} \mathrm{\rho} \mathrm{k}^{\mathrm{j} /}$ 'chef' becomes [' $\mathrm{k}^{\mathrm{h}} \mathrm{\textrm {h }} \mathrm{k}^{\mathrm{hj}} \mathrm{j}$ ]. In order to look at pre-palatal raising before plain velars, we need $/ \varepsilon$, œ/ followed by a velar, followed by a back vowel. This phonotactic combination is difficult to find in SCSw. words, but here we are helped by Rövarspråket. A word like /'jø:gi/ 'lied' will become /jojø:' gjogi/ in Rövarspråket. The /ø:/ will shorten to œ by unstressed vowel shortening, and we will then have a sequence ...œgj..., which has everything we are looking for. The full derivation of this word is shown in (11):

$\begin{array}{ll}\text { SCSw. UR } & \text { /'jø: gj/5 } \\ \text { Rövarspråket UR } & \text { /jojø:' 'gjogj/ } \\ \text { Shortening } & \text { jojœ' gjog } \\ \text { Depalatalization } & \text { jojø' gogj } \\ \text { Raising } & \text { jojø ' gogj } \\ \text { Other rules } & \text { jojø' 'gogj: } \\ \text { SR } & \text { [jojø'gogj:] } \\ \text { Translation } & \text { lied }\end{array}$

5 I write the front rounded vowel of this word using the symbol traditionally chosen in the linguistic literature on Swedish. In modern SCSw., the pronunciation is [œ:] for most people, and even approaches [๔:] for some. This notational choice makes the derivation look like it contains a Duke of York derivation in the quality of this vowel: first $\varnothing$, then $œ$, and finally back to ø. This is nothing more than an artifact of the notation. 
Notice that pre-palatal raising applies even before the plain velar $[\mathrm{g}]$, suggesting that a phonetic palatal gesture is not needed to trigger raising. The fact that Rövarspråket is used also demonstrates the productivity of raising in this environment. In light of this, one could revise the phonetic explanation for raising so that palatal or velar gestures are triggers. Raising before velars is familiar from patterns in other languages, such as /æa/-tensing in many varieties of American English (Labov 1994, Mielke, Carignan, and Thomas 2017). However, this revised explanation will not do either: /h/, a plain, unpalatalized velar for many speakers (see Ladefoged and Maddieson 1996: 171-172), never triggers pre-palatal raising:

$$
\begin{aligned}
& \text { UR SR Translation } \\
& \text { /'mefmet/_ ['mef:met } \left.{ }^{\mathrm{h}}\right] \quad \text { Mehmet (name) } \\
& \text { *['mef:met } \left.\mathrm{t}^{\mathrm{h}}\right]
\end{aligned}
$$

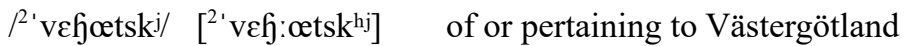

$$
\begin{aligned}
& \left.*{ }^{2}{ }^{2} \text { vef:œetsk }{ }^{\mathrm{hj}}\right]
\end{aligned}
$$

A final defense of the phonetic hypothesis might be that $/ \mathrm{h} /$ is a fricative, while $/ \mathrm{k}^{\mathrm{j}}, \mathrm{g}^{\mathrm{j}}, \mathrm{j}^{\mathrm{j} /}$ are stops. The tongue does not need to raise as high for a velar fricative as for a velar stop, and perhaps this is responsible for the absence of coarticulatory raising in the preceding vowel. But remember from (7) that $/ \mathrm{j} /$, an approximant, ${ }^{6}$ also triggers raising. The degree of stricture, therefore, seems to be irrelevant. The takeaway point from this discussion of raising should be that a purely phonetic definition of triggers for raising is difficult if not impossible to find. Instead, the triggers seem easiest to define in phonological terms, as all and only phonologically palatal consonants. In featural terms, they could be characterized as the class [+consonant, -back]. If the generalization about pre-palatal raising can only be stated at the phonological level, this suggests that the process has been phonologized, and is not just a coarticulatory phonetic effect (cf. Iosad 2017 on Welsh). If this is correct, there are implications for nasal assimilation. Assuming that phonetics applies after phonology, to its output, it is not possible for a phonetic process to precede a phonological one. (10) above showed that nasal assimilation must feed, and therefore precede, pre-palatal raising. This means that assimilation cannot be purely phonetic, and must also have been phonologized. Providing a phonological analysis of nasal assimilation is the goal of the rest of this section.

So far, the only data I have shown on SCSw. nasal assimilation is in (9), where /n/ always surfaces as a nasal stop. However, this is not the only possible outcome of assimilation, as shown in the impressionistic narrow transcriptions in (13):

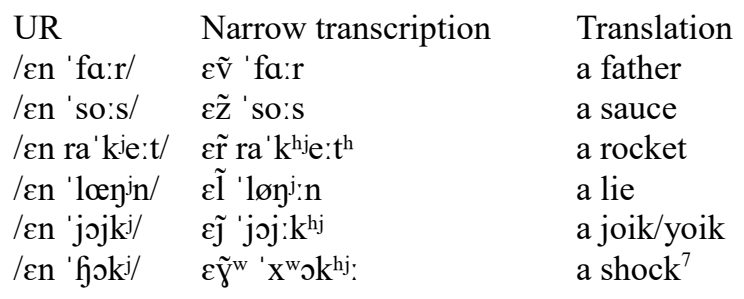

Assimilation in degree of stricture is not often mentioned in treatments of SCSw. Even authors who cite examples of it, such as Riad (2014), may describe the phenomenon as assimilation only for place: "By nasal assimilation, the coronal nasal assimilates to the place of articulation of a following segment. It is thus a case of regressive place assimilation" (Riad 2014: 88). However, it seems as if $/ \mathrm{n} /$ may assimilate for any feature except [nasal]: /n/ always surfaces with nasality. ${ }^{8}$ I propose that assimilation should be analyzed using phonetic underspecification (see Keating 1988 for the term): the surface forms in (13) have /n/

6 /j/ may also be a fricative /j/ for many speakers, but the same argument still holds.

7 The narrow transcription of this form assumes my idiolect's realization of $/ \mathrm{h} /$ as $\left[\mathrm{x}^{\mathrm{w}}\right]$.

$8 \mathrm{In}(13) / \mathrm{n} /$ also surfaces as voiced in all environments, but I will await phonetic work before claiming that there is no voicing assimilation to following voiceless consonants. 
surfacing as a feature bundle consisting of only [+nasal], underspecified for all other features. Using $\mathrm{N}$ as shorthand for this underspecified feature bundle, the nasal assimilation rule can then be written as follows:

$$
\mathrm{n} \rightarrow \mathrm{N} /{ }_{-}[+ \text {consonant }]
$$

The surface forms from (13) are then as follows:

\begin{tabular}{|c|c|c|}
\hline UR & SR & Translation \\
\hline /عn 'fa:r/ & [eN 'fa:r] & a father \\
\hline /عn 'so:s/ & [eN 'so:s] & a sauce \\
\hline /en ra'kje:t/ & {$\left[\varepsilon N \mathrm{ra}^{\prime} \mathrm{k}^{\mathrm{hj}} \mathrm{e}: \mathrm{t}^{\mathrm{h}}\right]$} & a rocket \\
\hline /عn 'lœnjn/ & [eN 'løy $]^{\mathrm{j}: \mathrm{n}}$ & a lie \\
\hline 'jojki/ & {$\left[\varepsilon N^{\prime} j j j: k^{h j}\right]$} & a joik/yoik \\
\hline n 'fok & [ $\varepsilon \mathrm{N}$ ' $\left.6 \mathrm{k}^{\mathrm{hj}}:\right]$ & a shock \\
\hline
\end{tabular}

Phonetically, these sequences should be realized as a smooth interpolation between the preceding and following sounds, with the only requirement that there is nasality in the transition. In a form like /en 'so:s/ 'a sauce', the body is effectively being told to get from an $[\varepsilon]$ target to an $[\mathrm{s}]$ target, along some path that passes through a stage of nasality. We may start off with a target-like $\varepsilon$, followed by a nasalized $\tilde{\varepsilon}$ before the features of the [s] are apparent. As we move further away from the vowel, features from [s] may begin to creep in, giving frication and a grooved tongue shape for something like z̃. Finally the effects of the vowel and the nasality fade away and we are left with a target-like s. This situation in SCSw. can be compared with Kuroda's (1965) description of nasal assimilation in Japanese:

The phonetic realization of the nasalized consonantal mora [i.e. the moraic nasal - SA] may best be described as a nasalized continuous transition from the preceding segment to the following one. When the following segment is a consonant, the nasalized mora consonant has the same point and manner of articulation as that consonant; for example, before $\underline{\mathrm{p}}, \underline{\mathrm{b}}$, or $\underline{\mathrm{m}}$, the nasalized mora consonant is $\underline{\mathrm{m}}$, but before $\underline{\mathrm{s}}$ it becomes a nasalized (and voiced) $\underline{\mathbf{s}}$, which we shall denote by $\underline{\tilde{s}} . "$ (Kuroda 1965: 201-202)

For Japanese, this description has been experimentally verified by Kochetov's (2014) study using electropalatographic (EPG) data. Kochetov mentions that there is some gradience in both place and manner assimilation, as expected if there is a smooth transition from the preceding vowel to the following consonant. It is worth mentioning that Kochetov's stimuli involved a language game, in order to verify that the observed assimilation patterns were productive. For SCSw., I am not aware of any experimental data confirming or falsifying the description of assimilation provided above. However, my account predicts that the patterns observed for Japanese by Kochetov should also be observed in SCSw.

If my description of SCSw. proves to be correct, we have to revisit the formulation of pre-palatal

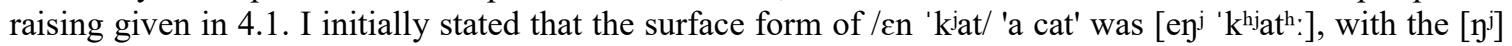
triggering pre-palatal raising of the preceding vowel. But if this form is really [ $\mathrm{eN}^{\mathrm{h}} \mathrm{k}^{\mathrm{hj}} \mathrm{t}^{\mathrm{h}} \mathrm{]}$, with an underspecified $\mathrm{N}$, why is there pre-palatal raising? I propose that the underlying $/ \varepsilon /$ in this form is raised not because of the nasal, but because of the $/ \mathrm{k}^{\mathrm{j}} /$. Raising is triggered across the nasal, as it lacks place features after assimilation has applied. The derivation of 'a cat' is shown in (16): 


\begin{tabular}{|c|c|}
\hline UR & /عn 'kjat/ \\
\hline Assimilation & $\varepsilon \mathrm{N}^{\prime} \mathrm{k}^{\mathrm{j} a t}$ \\
\hline Raising & eN 'kjat \\
\hline Other rules & eN ' $k^{\text {hja }} t^{\mathrm{h}}$ : \\
\hline SR & {$\left[\mathrm{eN}\right.$ ' $\mathrm{k}^{\mathrm{hj}} \mathrm{a}^{\mathrm{h}} \mathrm{t}$ ] } \\
\hline
\end{tabular}

Wrapping up our discussion of pre-palatal raising and nasal assimilation, I have argued that both of these processes are part of the phonology of SCSw. Pre-palatal raising seems to resist a description in purely phonetic terms, and the generalization is instead more successfully stated at the phonological level. Rövarspråket was used to make this argument, and also showed us that raising is productive. This illustrates one way of using language games to investigate the phonetics-phonology interface, and to find out whether a process is phonetic or phonological. Nasal assimilation creates new contexts where the phonological raising rule can apply, and must therefore also have been phonologized. The output of nasal assimilation was argued to be a feature bundle underspecified for everything except [nasal]. This approach makes a phonetic prediction about the gradient nature of assimilation which is as yet untested on SCSw. data. I leave this as an open prediction, allowing future research to confirm or falsify the theory outlined here.

\section{Conclusions}

In this paper, we have seen two case studies of language games in phonology, both using data from Rövarspråket to solve problems in the phonology of Standard Central Swedish. I have argued that both language-specific and general theoretical questions can be answered by considering language game data. The ability of language games to manipulate existing words in a language allows us to test the productivity of phonological generalizations, and often provides empirical evidence for the abstractions proposed by phonologists. I have used Rövarspråket to investigate four phonological processes, as well as the interactions between them. My conclusions about Swedish can be summarized as follows: 1) both nasal assimilation and pre-palatal raising have been phonologized, and 2) these rules are in a feeding relationship, while 3) the phonological rules of unstressed vowel shortening and centralization before $/ \mathrm{r} /$ exemplify counterfeeding. In the investigation of assimilation and raising we saw ways in which language games can shed light on the phonetics-phonology interface, specifically on the phonetic or phonological status of certain processes. The counterfeeding between shortening and centralization was brought to bear on the theoretical debate about opacity, arguing against theories which explicitly rule out the possibility of opaque interactions. It is my hope that this paper will stimulate more work on language games, and on those empirical and theoretical phenomena that they can help us understand.

\section{References}

Al-Mozainy, Hamza Q. (1981) Vowel alternations in a Bedouin Hijazi Arabic dialect: abstractness and stress. Dissertation. University of Texas at Austin.

Andersson, Samuel (2016) Sieves and Herrings: For Distinctive Vowel Length in Swedish. Ms. Lingbuzz/003136.

Andersson, Samuel (2017a) The Phonetics-Phonology Interface in Swedish. Talk presented at ULAB2017, April $8^{\text {th }}$, 2017. University of Cambridge.

Andersson, Samuel (2017b) Phonological Theory: The View from European Portuguese. BA Dissertation. University of Cambridge.

Anttila, Arto, Vivienne Fong, Štefan Beňuš, and Jennifer Nycz (2008) Variation and opacity in Singapore English consonant clusters. Phonology 25. 181-216.

Bagemihl, Bruce (1988) Alternate phonologies and morphologies. Dissertation. University of British Columbia.

Bagemihl, Bruce (1995) Language games and related areas. In J. Goldsmith (ed.). The Handbook of Phonological Theory. 697-712. Oxford: Blackwell.

Bale, Alan, and Charles Reiss (Forthcoming) Phonology: A Formal Introduction. MIT Press. 
Davis, Stuart (1993) Language Games. The Encyclopedia of Language and Linguistics. 1980-1985. Oxford/New York: Pergamon Press.

Elert, Claes-Christian (1981) Ljud och ord i svenskan 2. Uppsala: Almqvist \& Wiksell.

Green, Antony D. (2004) Opacity in Tiberian Hebrew: Morphology, not phonology. ZAS Papers in Linguistics 37 , December. 37-70.

Green, Antony D. (2007) Phonology Limited. Potsdam: Universitätsverlag Potsdam.

Hale, Mark, and Charles Reiss (2008) The Phonological Enterprise. Oxford: Oxford University Press.

Iosad, Pavel (2017) The phonologization of redundancy: Length and quality in Welsh vowels. Phonology 34:1. 121162.

Ito, Junko, and Armin Mester (2003) On the Sources of Opacity in OT: Coda Processes in German. In C. Féry and R. van de Vijver (eds.). The Syllable in Optimality Theory. 271-303. Cambridge: Cambridge University Press.

Keating, Patricia A. (1988) Underspecification in Phonetics. Phonology 5:2. 275-292.

Kochetov, Alexei (2014) Japanese Nasal Place/Stricture Assimilation: Electropalatographic Evidence. LabPhon14, July 25-27. Tokyo.

Kuroda, Sige-Yuki (1965) Generative Grammatical Studies in the Japanese Language. Dissertation. Massachusetts Institute of Technology.

Labov, William (1994) Principles of linguistic change. Volume 1: Internal factors. Oxford: Blackwell.

Ladefoged, Peter, and Ian Maddieson (1996) The Sounds of the World's Languages. Oxford: Blackwell.

McCarthy, John J. (1999) Sympathy and phonological opacity. Phonology 16:3. 331-399.

Mielke, Jeff, Christopher Carignan, and Erik R. Thomas (2017) The articulatory dynamics of pre-velar and pre-nasal /æ/-raising in English: An ultrasound study. The Journal of the Acoustical Society of America 142, 332. https://doi.org/10.1121/1.4991348.

Morén-Duolljá, Bruce (2013) The prosody of Swedish underived nouns: No lexical tones required. Nordlyd 40:1. 196248.

Reiss, Charles (2018) Substance Free Phonology. In S. J. Hannahs, and A. Bosch (eds.). The Routledge Handbook of Phonological Theory. Chapter 15. Oxford/New York: Routledge.

Riad, Tomas (2014) The Phonology of Swedish. Oxford: Oxford University Press.

Samuels, Bridget (2009) The Structure of Phonological Theory. Dissertation. Harvard University.

Samuels, Bridget (2011) A Minimalist Program for Phonology. In C. Boeckx (ed.). The Oxford Handbook of Linguistic Minimalism. 574-594. Oxford: Oxford University Press.

Sanders, Nathan (2003) Opacity and sound change in the Polish lexicon. Dissertation. University of California, Santa Cruz.

Sherzer, Joel (1970) Talking Backwards in Cuna: The Sociological Reality of Phonological Descriptions. Southwestern Journal of Anthropology 26:4. 343-353.

Sumner, Meghan Marie (2003) Testing the abstractness of phonological representations in Modern Hebrew weak verbs. Dissertation. State University of New York at Stony Brook.

Vaux, Bert (2008) Why the Phonological Component must be Serial and Rule-Based. In B. Vaux, and A. Nevins (eds.). Rules, Constraints, and Phonological Phenomena. 20-60. Oxford: Oxford University Press.

Vaux, Bert (2011) Language Games. In J. Goldsmith, J. Riggle, and A. C. L. Yu (eds.). The Handbook of Phonological Theory. Second Edition. 722-750. Oxford: Wiley-Blackwell.

Wenner, Lena (2010) När lögnare blir lugnare: En sociofonetisk studie av sammanfallet mellan kort $\ddot{o}$ och kort $u$ i uppländskan. Dissertation. Uppsala Universitet.

Zhang, Jie, Yuwen Lai, and Craig Turnbull-Sailor (2006) Wug-Testing the "Tone Circle" in Taiwanese. In D. Baumer, D. Montero, and M. Scanlon (eds.). Proceedings of the $25^{\text {th }}$ West Coast Conference on Formal Linguistics. 453461. Somerville, MA: Cascadilla Proceedings Project. 